\title{
DETERMINATION OF MATERIAL RESPONSE AND OPTIMIZATION OF JOHNSON-COOK DAMAGE PARAMETERS OF ALUMINIUM 7075 ALLOY
}

\author{
${ }^{1}$ Burak BAL \\ ${ }^{1}$ Department of Mechanical Engineering, Abdullah Gül University, 38080 Kayseri, Turkey \\ rburak.bal@agu.edu.tr
}

(Geliş/Received: 06.09.2017; Kabul/Accepted in Revised Form: 28.11.2017)

\begin{abstract}
The effects of rolling direction and notch radius on the mechanical response of aluminium 7075-T651 alloy were investigated and the Johnson-Cook damage parameters of aluminium 7075-T651 alloy on both rolling directions were determined. Specifically, mechanical responses of aluminium 7075T651 along the rolling direction and perpendicular to the rolling direction were obtained from monotonic tensile tests. 56 tensile tests in total were performed on notched specimens with 3 different notch radiuses and smooth specimens. Tensile tests were repeated 7 times for each case to ensure the consistency and to obtain the closest mechanical response to the real mechanical response with minimum error. Experimental findings revealed that being perpendicular to the rolling direction deteriorates the elongation at failure dramatically but can increase the mechanical properties in elastic region. The final areas of the fractured samples, used for the calculation of Johnson-Cook damage parameters, were measured by an optical microscope. The Johnson-Cook damage parameters of aluminium 7075-T651 alloy for different applications were computed by Levenberg-Marquardt optimization method. Collectively, this study opens the venue for accurate damage simulations of aluminium 7075-T651 along the rolling direction and perpendicular to the rolling direction for different applications.
\end{abstract}

Key Words: Aluminium, Johnson-Cook, Levenberg-Marquardt optimization, Rolling direction, Tensile test

\section{Alüminyum 7075 Alaşiminin Malzeme Davranişinin Tespiti ve Johnson-Cook Hasar Parametrelerinin Optimizasyonu}

ÖZ: Alüminyum 7075-T651 alaşımının mekanik davranışına hadde yönünün ve çentik yarıçapının etkileri incelenmiş ve bu alaşımın iki farklı hadde yönü için Johnson-Cook hasar katsayıları hesaplanmıştır. Spesifik olarak, hadde yönünde ve hadde yönüne dik olarak hazırlanmış alüminyum 7075-T651 alaşımının mekanik davranışları çekme testleri sonucunda belirlenmiştir. 3 farklı çentik yarıçapındaki numunelere ve çentiksiz numunelere olmak üzere toplamda 56 adet çekme testi gerçekleştirilmiştir. Her bir çekme testi tutarlılığı sağlamak ve gerçek mekanik davranışa en yakın sonucu en düşük hata ile elde etmek adına 7 kere tekrarlanmıştır. Deneysel bulgular hadde yönüne dik olmanın uzamayı azalttığını fakat elastik bölgedeki mekanik özellikleri arttırabildiğini göstermektedir. Johnson-Cook hasar katsayılarının hesaplanmasında kullanılan kırılmış yüzey alanları optik mikroskop ile ölçülmüştür. Alüminyum 7075-T651 alaşımının Johnson-Cook hasar katsayıları farklı uygulama alanları için Levenberg-Marquardt optimizasyon methodunu kullanarak hesaplanmıştır. Bu sebeple, bu çalışma hadde yönünde ve hadde yönüne dik olarak hazırlanmış alüminyum 7075-T651 alaşımının farklı uygulama alanlarındaki hassas hasar simulasyonları için yol gösterici bir alan açmaktadır.

Anahtar Kelimeler: Alüminyum, Johnson-Cook, Levenberg-Marquardt optimizasyonu, Hadde yönü, Çekme testi 


\section{INTRODUCTION}

Using lightweight structural materials in design without sacrificing from safety is very crucial for several applications in the modern world. Owing to the promising combination of lightweight, high strength, good machinability, corrosion resistance and surface finish, aluminium (Al) alloys are the material of choice for different applications, such as automotive, aviation, marine and rail transport (Hirsch and Al-Samman, 2013; Zhang et al., 2015). Aluminium has a face-centered cubic (fcc) crystal structure at room temperature. Al 7075-T6 alloy is one of the highest strength alloys with high fracture toughness and low fatigue crack growth rate, which makes it the material of choice for the aforementioned applications, among other $\mathrm{Al}$ alloys (Senthil et al., 2017). Therefore, determining the mechanical behavior of Al 7075-T6 under different loading scenarios is of utmost importance in order to use them in these application areas.

Determination of quasi-static and static properties of Al 7075-T6 alloy is relatively easy by uniaxial tensile testing. However, determining the dynamic properties of materials is not as easy as obtaining static material response. In order to define the dynamic material behavior under various conditions, several empirical, semi-empirical or physically-based material models have been proposed including the Zerilli-Armstrong material model (Yuan et al., 2013), the mechanical threshold stress model (Cai et al., 2010) and the Khan-Huang-Liang (Chen et al.,2015) constitutive model. Among all constitutive models, Johnson-Cook, which includes strain hardening, strain rate hardening and thermal softening, is the most widely used material model to represent the visco-plastic behavior of materials. These phenomenological material models are calculated from flow stress response of materials (Chen et al., 2015). In particular, flow stress is generally proportional to the strain rate and inversely proportional to temperature.

Johnson-Cook material and Johnson-Cook damage models have been used in Finite Element (FE) simulations as a visco-plastic material behavior input for decades to simulate material and damage behavior of materials for various applications, such as machining, impact and ballistic (Chen et al., 2015; Thepsonthi and Özel, 2015). Therefore, accurate calculation of Johnson-Cook damage model parameters is very critical for accurate FE simulations. In addition, Johnson-Cook damage model parameters are known to be sensitive to the rolling direction. Therefore, while determining Johnson-Cook damage model parameters of Al 7075-T651 alloy, the effects of rolling direction should also be taken into consideration. The determination of Johnson-Cook damage model parameters of Al 7075-T651 alloy has been studied with experimental methods including tensile and split-Hopkinson pressure bar tests (Brar and Joshi, 2012; Brar et al., 2009). As a result of these studies, several Johnson-Cook damage model parameters have been determined for an $\mathrm{Al}$ 7075-T651 alloy both in the rolling direction and perpendicular to the rolling direction. However, these results are not precise due to the low number of repetitions of experiments. In addition, to the best of the author's knowledge, there is no study which determines the Johnson-Cook damage model parameters of Al 7075-T651 alloy for different application types, such as conservative, demanding or normal.

In this study, accurate Johnson-Cook damage model parameters of Al 7075-T651 alloy both in the rolling direction and perpendicular to the rolling direction were determined by tensile tests that were repeated 7 times to ensure the consistency of the results, and an iterative Levenberg-Marquardt optimization method. In addition, the effects of notch radius on the material response both in the rolling direction of Al 7075-T651 alloy and perpendicular to the rolling direction, as well as the effects of rolling direction on the material response at room temperature were determined. Furthermore, the relationship between stress triaxiality and equivalent plastic strain was revealed and with the help of maximum, average and minimum equivalent plastic strain values, different Johnson-Cook damage model parameters were computed for different application areas. Overall, the study presented herein constitutes a significant guideline for accurate FE simulations of Al 7075-T651 alloy for several applications. The originality of the current study can be summarized as: 1) Due to the fact that each experiment was repeated 7 times for each case, the mechanical response and the Johnson-Cook damage 
parameters of Al 7075-T651 alloy results are very accurate, 2) Al 7075-T651 alloy with four different notch radiuses, which induces four different stress triaxiality factors, and on two different rolling directions were tensile tested. Therefore, the positive and detrimental effects of both stress triaxility and rolling direction in elastic and plastic regions have been determined, 3) Johnson-Cook damage parameters for $\mathrm{Al} \mathrm{7075-T651} \mathrm{alloy} \mathrm{for} \mathrm{both} \mathrm{rolling} \mathrm{directions} \mathrm{were} \mathrm{computed} \mathrm{for} \mathrm{different} \mathrm{application}$ areas.

\section{MATERIAL AND METHOD}

The material investigated in this study is aluminium 7075-T651 alloy. The chemical composition of the studied material is presented in Table 1 . Tensile test specimens were prepared from the as-is material in the rolling direction and perpendicular to the rolling direction by turning and milling operations. In order to investigate the effect of stress triaxiality, corresponding mechanical behavior and Johnson-Cook damage parameters, tensile tests were conducted on both smooth samples and notched samples. Figure 1 shows technical drawings of both smooth and notched tensile test specimens. Ro represents the notch radius of the notched specimens. Specifically, 4 different notch radiuses were used for the preparation of specimens. Radiuses and corresponding gauge lengths of the specimens are listed in Table 2. The notch radii were selected as in Table 2 to be consistent with literature.

Table 1. Chemical composition of the studied material (in wt.-\%)

\begin{tabular}{|lllllll|}
\hline Al & Zn & Mg & Cu & Fe & Si & Cr \\
\hline 89.1 & 5.8 & 2.5 & 1.4 & 0.2 & 0.3 & 0.2 \\
\hline
\end{tabular}
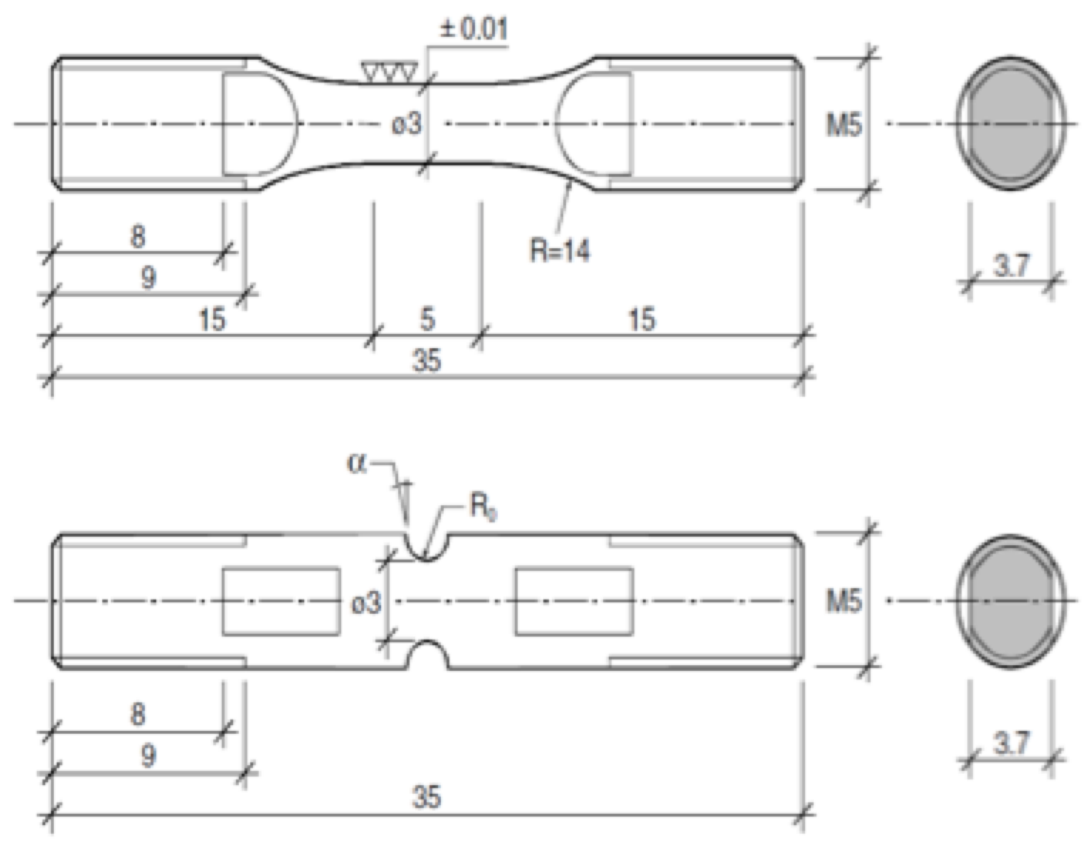

Figure 1. Specimen dimensions of smooth specimen and notched specimen for tensile testing (unit:mm) 
Table 2. Notch radius and gauge length of the studied material (unit: $\mathrm{mm}$ )

\begin{tabular}{|c|cc|}
\hline Material & Notch radius (R) & Gauge length \\
\hline \multirow{3}{*}{ Rolling Direction } & 0 & 5 \\
& 0.4 & 0.74 \\
& 0.8 & 1.52 \\
Perpendicular to rolling direction & 2 & 3.46 \\
& 0 & 5 \\
& 0.4 & 0.74 \\
& 0.8 & 1.52 \\
& 2 & 3.46 \\
\hline
\end{tabular}

A servohydraulic tensile/fatigue test machine, Instron 8801 , was used to conduct tensile tests. All tests were conducted at room temperature and a strain rate of $1 \times 10^{0} \mathrm{~s}^{-1}$. Prior to the experiments the surface of the material was ground (with silicon carbide paper from 60 grit to 1200 grit) and polished (with a diamond product from 6 micron to 1 micron) to reduce the microcracks and residual stress on the surface. Each uniaxial monotonic tensile test was repeated seven times for each case to ensure the consistency of results. Therefore 7 repetitions for 8 specimens, in total 56 tensile tests, were performed. All experiments were conducted according to the ISO standards. Displacement was measured by an extensometer, force was measured by a load cell and they were converted into stress and strain by classical strength equations, given below:

$$
\begin{gathered}
\sigma_{\text {eng }}=\frac{F}{A_{0}} \varepsilon_{\text {eng }}=\frac{\Delta l}{l_{0}} \\
\sigma_{\text {true }}=\sigma_{\text {eng }}\left(1+\varepsilon_{\text {eng }}\right) \varepsilon_{\text {true }}=\operatorname{Ln}\left(1+\varepsilon_{\text {eng }}\right)
\end{gathered}
$$

where F, A, 1 represent the force, initial gauge area of the specimen and length, respectively.

After the tensile tests, the final cross-section area of the specimens was measured by an optical microscope (euromex, NexiusZoom). The calculation method of the Johnson-Cook damage parameters of aluminium 7075-T651 alloy for different applications is explained in the following section.

\section{THEORY AND CALCULATIONS}

The Johnson-Cook multiaxial material model represents the material response under different loading scenarios. It includes strain hardening, strain rate hardening and thermal softening as follows (Binder et al., 2015; Bobbili et al., 2015; Bobbili et al., 2016):

$$
\bar{\sigma}=\left[A+B \varepsilon^{n}\right]\left[1+C \operatorname{Ln}\left(\frac{\dot{\bar{\varepsilon}}^{p l}}{\dot{\varepsilon}_{0}}\right)\right]\left[1-T^{* m}\right]
$$

where $\bar{\sigma}$ is the equivalent flow stress, A, B, C, n, m are material constants, $\bar{\varepsilon}_{f}^{p l}$ is the equivalent plastic strain at fracture, $\dot{\varepsilon}_{0}$ is the reference strain rate and $T^{*}$ is the non dimensional temperature. Similar to the flow stress model, the failure model was proposed by quantifying damage accumulation via damage parameter, which is $D=\sum_{t=0} \frac{\Delta \varepsilon}{\varepsilon_{J C}^{f}}$ (Kupchella et al., 2015). 
The Johnson-Cook ductile failure model can be defined as (Chocron, et al. 2011; Kupchella et al., 2015)

$$
\bar{\varepsilon}_{f}^{p l}\left(\sigma^{*}, \dot{\bar{\varepsilon}}^{p l}, T^{*}\right)=\left[D_{1}+D_{2} e^{D_{3} \sigma^{*}}\right]\left[1+D_{4} \operatorname{Ln}\left(\frac{\dot{\bar{\varepsilon}}^{p l}}{\dot{\varepsilon}_{0}}\right)\right]\left[1+D_{5} T^{*}\right]
$$

where $\sigma^{*}$ is the stress triaxiality factor (STF) and $D_{1}$ to $D_{5}$ are Johnson Cook damage parameters, which can be calculated through tensile and torsion experiments on notched and smooth specimens. Since the aim of the current study is to determine $D_{1}-D_{3}$, tensile tests under a medium strain rate, $10^{0} 1 / \mathrm{s}$, were conducted at room temperature. The selected strain rate is sufficient for the calculation of these parameters as discussed earlier (Brar and Joshi, 2012; Zhang et al., 2015).

As it can be seen from equation 3, Johnson-Cook failure model depends on the STF. The definition of STF is the ratio between hydrostatic stress and equivalent stress, which can be expressed as $S T F=\sigma_{h} / \bar{\sigma}$. STF represents the stress state on the conical surface in Figure 2. In addition, Lode angle, $\theta$, takes the angular orientation of the yield surface into consideration and it is related to the normalized third deviatoric stress invariant (Keshavarz et al., 2014; Valoppi et al., 2017). Specifically, for smooth material, STF is equal to $1 / 3$ under uniaxial tension and $-1 / 3$ under uniaxial compression. However, STF changes for notched specimens since more local deformation occurs around notch region. Therefore STF can be calculated as

$$
\sigma^{*}=1 / 3+\operatorname{Ln}\left(1+a_{0} / 2 R_{0}\right)
$$

where $a_{0}$ is the specimen radius at the notch center and $R_{0}$ is the original specimen radius. Stress triaxiality factor values for each configuration are listed in Table 3.

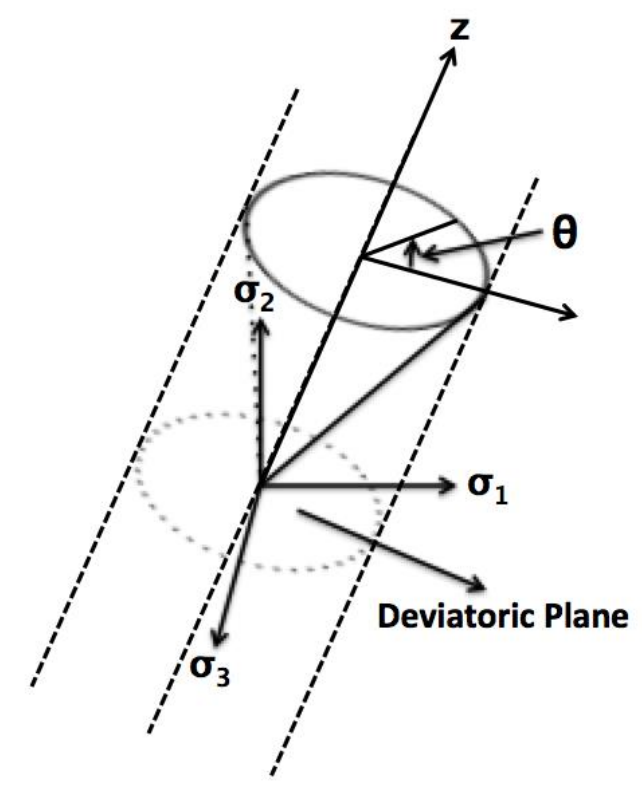

Figure 2. Schematic representation of deviatoric plane and Lode angle on principal stress states.

Table 3. Stress triaxiality factors for each configuration

\begin{tabular}{|c|c|}
\hline Material & $\boldsymbol{\sigma}^{*}$ \\
\hline Smooth & $1 / 3$ \\
R0.4 & 1.39 \\
R0.8 & 0.99 \\
R2 & 0.65 \\
\hline
\end{tabular}


Equivalent plastic strain in equation 3 can be calculated through equation 6 . In equation 6 , Ao is the initial cross-section area and $\mathrm{A}_{\mathrm{f}}$ is the final cross section area. Since a notch is introduced to the sample to provide deformation around notched section, local strain calculation with cross-section area instead of length gives desired equivalent plastic strain values. During deformation, the cross section of specimens changes to ellipse. Both diameters of ellipse were measured by an optical microscope and final area was calculated by the area of ellipse formula. Initial and final cross-section areas of the specimens are given in Table 4.

$$
\bar{\varepsilon}_{f}^{p l}=\operatorname{Ln} \frac{A_{0}}{A_{f}}
$$

Table 4. Initial and fracture cross-section areas of the specimens.

\begin{tabular}{|c|cc|}
\hline Material & Initial Area $\left(\mathbf{m m}^{2}\right)$ & Final area $\left(\mathbf{m m}^{2}\right)$ \\
\hline Smooth (Rolling Direction) & 7.06 & 5.72 \\
R0.4 (Rolling Direction) & 7.06 & 6.29 \\
R0.8 (Rolling Direction) & 7.06 & 5.85 \\
R2 (Rolling Direction) & 7.06 & 6.02 \\
$\begin{array}{c}\text { Smooth (Perpendicular to the } \\
\text { rolling direction) }\end{array}$ & 7.06 & 6.31 \\
R0.4 (Perpendicular to the rolling \\
$\begin{array}{c}\text { direction) } \\
\text { R0.8 (Perpendicular to the rolling } \\
\text { direction) }\end{array}$
\end{tabular}

Due to the fact that investigated Johnson-Cook damage parameters are $D_{1}, D_{2}$ and $D_{3}$, equation 4 becomes

$$
\bar{\varepsilon}_{f}^{p l}\left(\sigma^{*}, \dot{\bar{\varepsilon}}^{p l}, T^{*}\right)=\left[D_{1}+D_{2} e^{D_{3} \sigma^{*}}\right]
$$

In equation 7 , there are 3 unknowns and 4 equations since there are 1 smooth and 3 notched specimens. Therefore, the system in this problem is overdetermined, which is inconsistent. Therefore, an iterative least square method should be used to determine Johnson-Cook damage parameters. In this study, iterative Levenberg-Marquardt optimization method (Børvik et al., 2005; Brar and Joshi, 2012; Brar et al., 2009) was used to determine $D_{1}, D_{2}, D_{3}$ Johnson-Cook damage parameters and an iterative code was prepared in Matlab platform.

\section{RESULTS AND DISCUSSION}

Figure 3 shows the true stress - true strain curves of notched and smooth Al 7075 alloys along rolling direction. Specimen with a $0.4 \mathrm{~mm}$ notch radius shows the best ductility and strength combination. On the other hand, specimen with a $2 \mathrm{~mm}$ notch radius has the worst ductility and smooth specimen has the worst strength values compared to other specimens. If the smooth sample is not considered, it is clear that as the stress triaxiality increases both strength and ductility of the $\mathrm{Al} 7075$ alloy along rolling direction also increases. Specifically, the ductility of the material increased from 0.1 to 0.36 and strength of the material increased from 802.2 $\mathrm{MPa}$ to $1239.5 \mathrm{MPa}$ with increasing stress 
triaxiality. The increase in the tensile stress with stress triaxiality has been reported previously for the Al 7075-T651 alloy and current results correspond well with previous studies (Senthil et al., 2017).

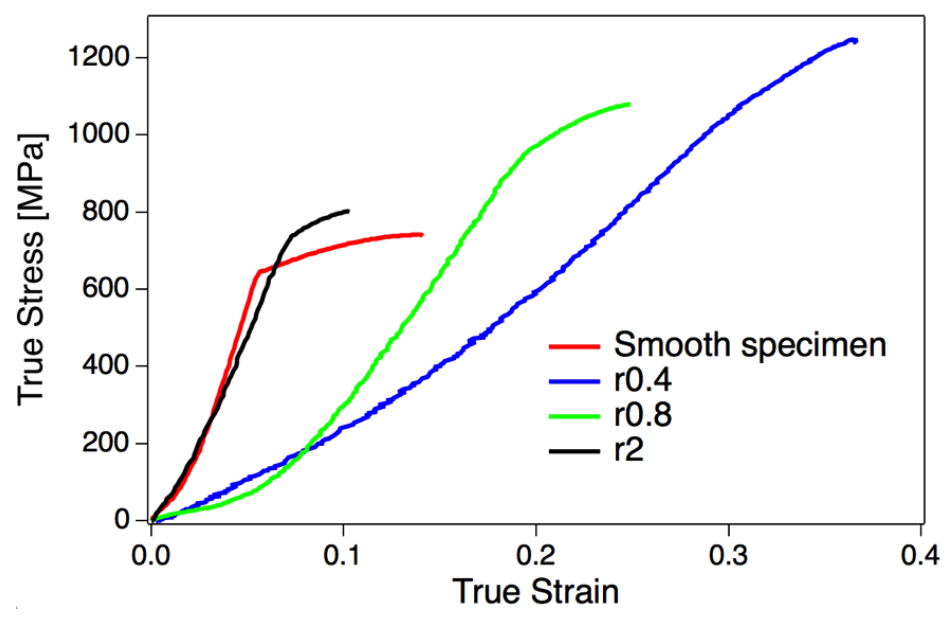

Figure 3. True stress - True strain behavior of Al 7075 alloy along rolling direction

Figure 4 shows the true stress - true strain curves of notched and smooth Al 7075 alloys perpendicular to the rolling direction. Specimen with a $0.4 \mathrm{~mm}$ notch radius has the best ductility and specimen with a $2 \mathrm{~mm}$ notch radius has the highest strength values. Similar to the rolling direction case, specimen with a $2 \mathrm{~mm}$ notch radius has the worst ductility and specimen with a 0.8 mm notch radius has the worst strength values compared to other specimens. If the smooth sample is not considered, it is clear that as the stress triaxiality increases, the ductility of the Al 7075 alloy perpendicular to the rolling direction also increases. Specifically, the ductility of the material increased from 0.07 to 0.24 with increasing stress triaxiality. The materials generally spend the given energy to the lattice distortion, deformation mechanisms formation, which are the driving force for plastic deformation, and heat. When the given energy cannot be accommodated plastically through deformation mechanisms or any other mechanisms fracture occurs. When we look at Figure 3 and Figure 4, on both directions, smooth specimens were deformed more after the yield point (plastic deformation) when compared to notched specimens. This result can be attributed to the fact that notched specimens spend the given energy to the localized deformation around the notched region elastically but cannot accommodate the given energy plastically. On the contrary, the deformation is uniform for the smooth specimens and the energy can be accommodated plastically for a certain period of time prior to the failure.

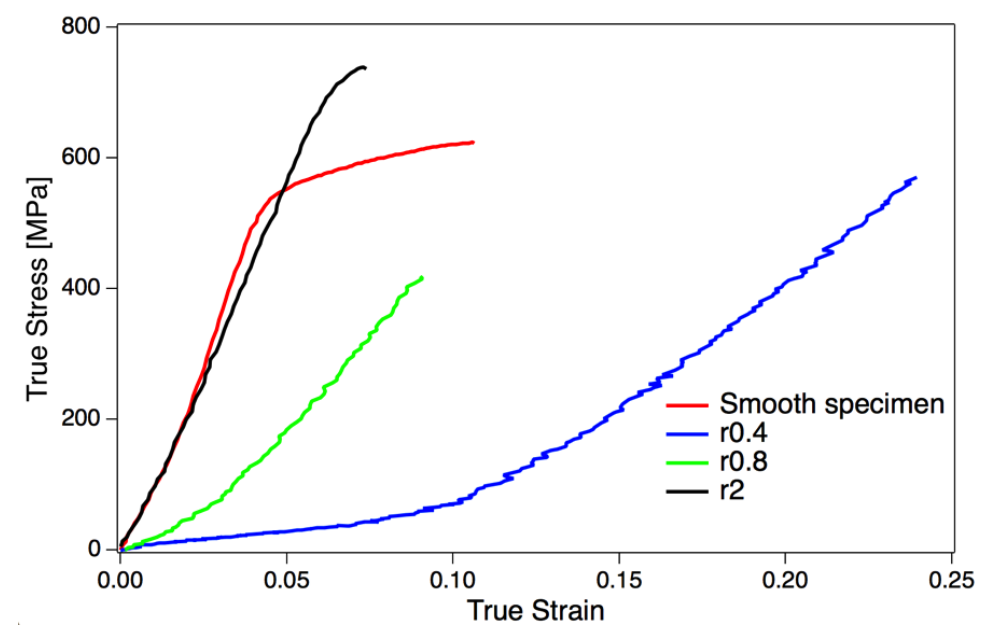

Figure 4. True stress - True strain behavior of Al 7075 alloy perpendicular to the rolling direction 
Figure 5(a-d) shows the effect of rolling direction on the stress-strain behavior of the Al 7075 alloy. It is clear that being perpendicular to the rolling direction deteriorates the elongation at failure dramatically so it proves that, Al 7075-T651 alloy has anisotropic properties. In particular, changing rolling direction to perpendicular to the direction reduced the ductility of $\mathrm{Al} 7075$ alloy by $\% 24$ for smooth specimen, \%34 for $0.4 \mathrm{~mm}$ notched specimen, \%64 for $0.8 \mathrm{~mm}$ notched specimen and \%28 for 2 $\mathrm{mm}$ notched specimen. On the other hand, the smooth specimen and the specimens with $0.8 \mathrm{~mm}$ and 2 $\mathrm{mm}$ notches have greater stress values at the same strain values up to yield stress when they are perpendicular to the rolling direction. This behavior could be very beneficial for applications which do not require high ductility levels, thus, the current finding also sheds light on the material selection process in design. However, the specimen with the $0.4 \mathrm{~mm}$ notch radius, which has the greatest stress triaxiality, has less stress values at the same strain values when it is perpendicular to the rolling direction even at the elastic region. This result indicates that the effect of stress triaxiality on the elastic response becomes dominant after critical stress triaxiality. Specifically, up to this critical stress triaxiality value, changing rolling direction to perpendicular to the direction reduces the ductility of Al 7075 alloy and increases the stress values at the elastic region but after the critical stress triaxiality value both ductility and stress values are deteriorated.
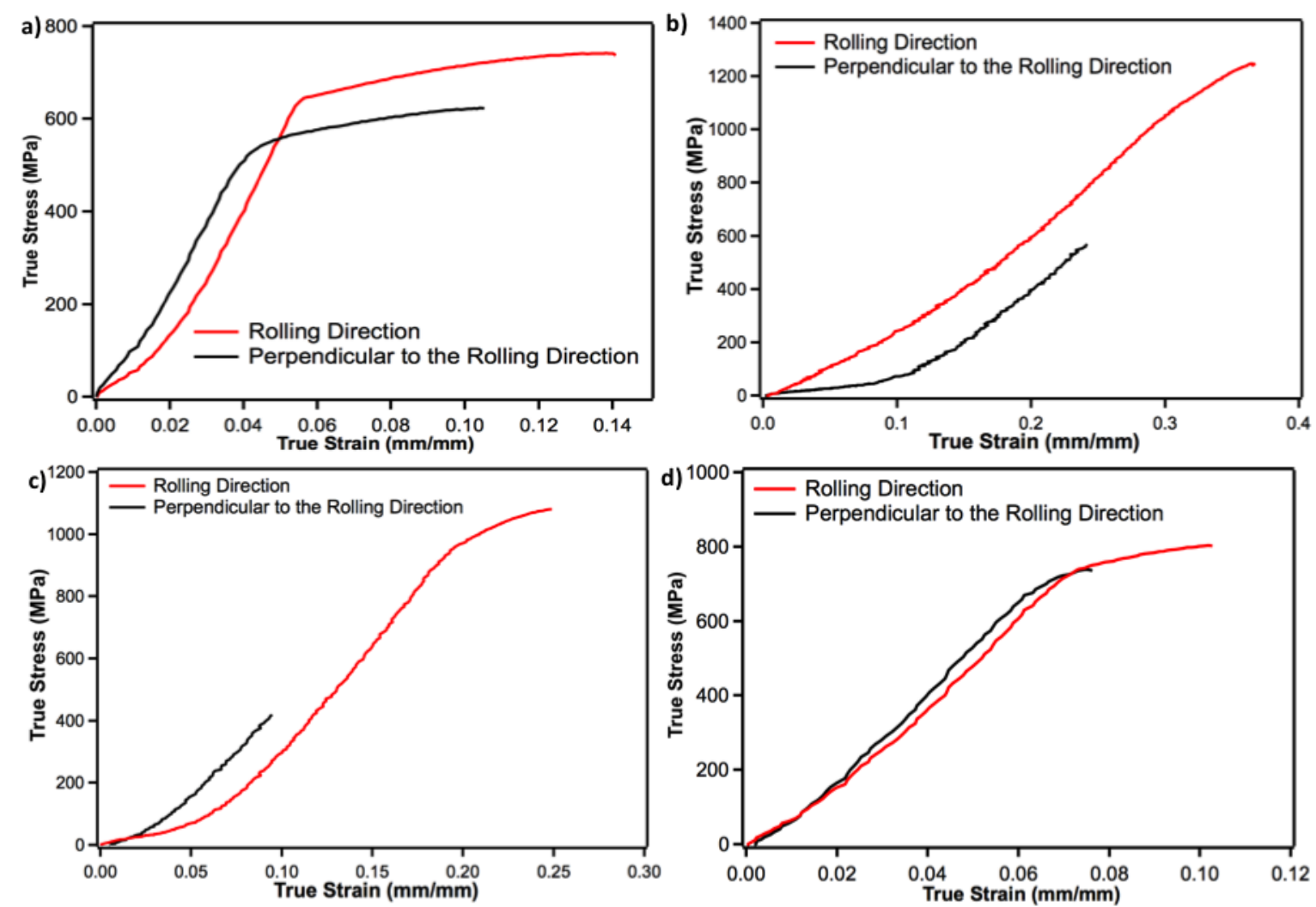

Figure 5. Comparison of the tensile behavior between rolling direction and perpendicular to the rolling direction a) smooth specimens b) R0.4 c) R0.8 d) R2

Figure 6 and Figure 7 show the dependence of equivalent plastic strain at fracture on the stress triaxiality factor for the specimen in the rolling direction and for the specimen perpendicular to the rolling direction, respectively. Equivalent plastic strain at fracture and stress triaxiality values were determined via equation 5 and equation 6, respectively. Three red points represent the maximum equivalent plastic strain, average equivalent plastic strain and minimum equivalent plastic strain at fracture. The failure equivalent strain for the smooth specimen is greater than that for the notched specimens for both rolling directions due to the neck formation, which promotes the triaxiality and this behavior corresponds well with previous studies (Bobbili et al., 2016; Choung et al., 2014; Wang and Liu, 
2016; Zhou et al., 2011). In addition, as the stress triaxiality increases, equivalent plastic strain at fracture values for both rolling directions decreases (Figures 6,7). This behavior is very reasonable and agrees well with previous studies since as the stress triaxiality factor increases, the size of voids also increases and critical stress for void coalescence decreases, which reduces the equivalent plastic strain at fracture (Bobbili and Madhu, 2016; Senthil et al., 2017). The parabolic behavior is also expected since as the void size increases, the critical stress for void coalescence decreases with the same exponential decay behavior.

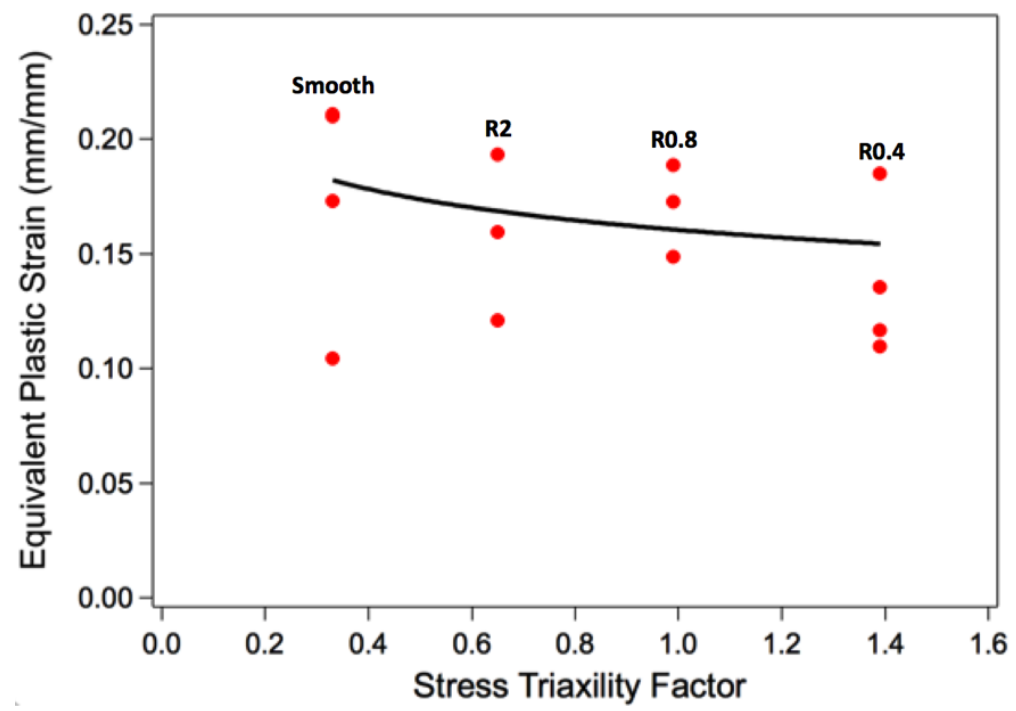

Figure 6. Equivalent plastic strain to fracture vs. stress triaxiality factor for the specimen in the rolling direction

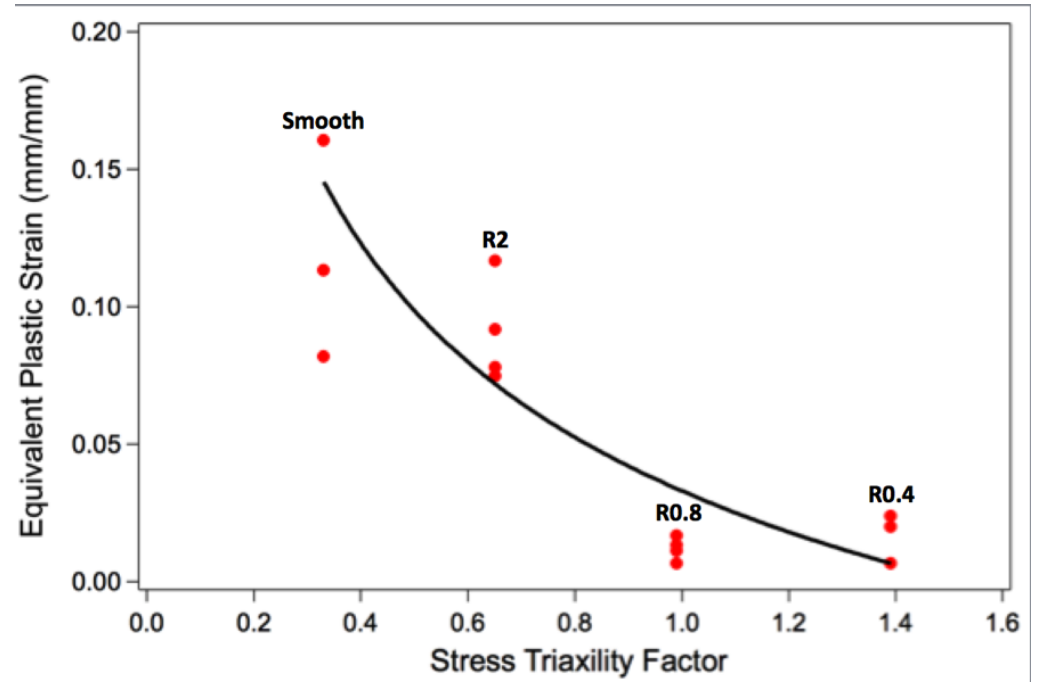

Figure 7. Equivalent plastic strain to fracture vs. stress triaxiality factor for the specimen perpendicular to the rolling direction

Johnson-Cook damage parameters were determined via equation 7 . Since there are three notched specimens and one smooth specimen, there are four equations and three unknowns, which is an overdetermined system. This overdetermined system was solved by the Levenberg-Marquardt optimization method. The computed Johnson-Cook damage parameters for the Al 7075-T651 alloy in the rolling direction and perpendicular to the rolling direction are listed in Table 5, 6 and 7. Specifically, Johnson-Cook damage parameters using the average equivalent plastic values are listed in Table 5 . These parameters can be used for ideal simulations that do not require any critical case. However, if there is any demanding application, which can be subject to high strain rate loadings and requires low 
weight and size but not safety first, Johnson-Cook damage model constants with maximum equivalent plastic strain values can be used. The Johnson-Cook damage model constants with maximum equivalent plastic strain values are listed in Table 6. Finally, for an application whose simulation is very critical and should be very safe, Johnson-Cook damage model constants with minimum equivalent plastic strain values can be used. The Johnson-Cook damage model constants with minimum equivalent plastic strain values are listed in Table 7. The calculated Johnson-Cook damage model constants agree well with previous studies (Brar and Joshi, 2012; Brar et al., 2009), however since a high number of experiments were carried out in this study, current results are more precise.

Table 5. Johnson-Cook damage model constants for Al 7075-T651 alloy.

\begin{tabular}{|c|ll|}
\hline Constant & Rolling Direction & Perpendicular to the rolling direction \\
\hline D1 & 0.116599 & 0.020000 \\
D2 & 0.093400 & 0.093300 \\
D3 & -0.544232 & -2.089870 \\
\hline
\end{tabular}

Table 6. Johnson-Cook damage model constants for Al 7075-T651 alloy with maximum equivalent plastic strain values.

\begin{tabular}{|c|ll|}
\hline Constant & Rolling Direction & Perpendicular to the rolling direction \\
\hline D1 & 0.1848 & -0.0088 \\
D2 & 0.0783 & 0.4678 \\
D3 & -3.3503 & -2.2433 \\
\hline
\end{tabular}

Table 7. Johnson-Cook damage model constants for Al 7075-T651 alloy with minimum equivalent plastic strain values.

\begin{tabular}{|c|ll|}
\hline Constant & Rolling Direction & Perpendicular to the rolling direction \\
\hline D1 & 0.1193 & 0.0066 \\
D2 & $4.12 \mathrm{E}-4$ & 0.0714 \\
D3 & 1.1230 & -1.7699 \\
\hline
\end{tabular}

\section{CONCLUSIONS}

In this study, the effect of rolling direction on the mechanical response of the Al 7075-T651 alloy was investigated. In addition, Johnson-Cook damage parameters for Al 7075-T651 alloy on both rolling directions were computed. From the work presented herein the following conclusions can be drawn:

1) The stress triaxiality is proportional to both strength and ductility of the $\mathrm{Al} 7075$ alloy along rolling direction. Also, being perpendicular to the rolling direction deteriorates the elongation at failure dramatically.

2) Being perpendicular to the rolling direction can enhance the mechanical properties in elastic region. This finding could be very beneficial for applications where high ductility levels are not required. 
Johnson-Cook damage parameters for Al 7075-T651 alloy both in the rolling direction and perpendicular to the rolling direction were computed for different application areas with minimum, maximum and average equivalent plastic strain at failure values.

\section{ACKNOWLEDGEMENTS}

B. Bal gratefully acknowledge the financial support provided by Aselsan A.Ş.

\section{REFERENCES}

Binder, M., Klocke, F., Lung, D., 2015, "Tool Wear Simulation of Complex Shaped Coated Cutting Tools", Wear, Vol. 330-331, pp. 600-607.

Bobbili, R., Ramakrishna, B., Madhu, V., Gogia, A. K., 2015, "Prediction of Flow Stress of 7017 Aluminium Alloy under High Strain Rate Compression at Elevated Temperatures", Defence Technology, Vol. 11, pp. 93-98.

Bobbili, R., Madhu, V., 2016, "Effect of Strain Rate and Stress Triaxiality on Tensile Behavior of Titanium Alloy Ti-10-2-3 at Elevated Temperatures", Materials Science and Engineering A, Vol. 667, pp. 3341.

Bobbili, R., Paman, A., Madhu, V., 2016, "High Strain Rate Tensile Behavior of Al-4.8Cu-1.2Mg Alloy", Materials Science and Engineering A, Vol. 651, pp. 753-762.

Børvik, T., Hopperstad, O. S., Dey, S., Pizzinato, E. V., Langseth, M., Albertini, C., 2005, "Strength and Ductility of Weldox 460 E Steel at High Strain Rates, Elevated Temperatures and Various Stress Triaxialities", Engineering Fracture Mechanics, Vol. 72, pp. 1071-1087.

Brar, N. S., Joshi, V. S., 2012, "Anisotropic Effects on Constitutive Model Parameters of Aluminum Alloys", AIP Conference Proceedings, Vol. 1426 (1), pp. 72-75.

Brar, N. S., Joshi, V. S., Harris, B. W., 2009, "Constitutive Model Constants for Al7075-T651 and Al7075T6", AIP Conference Proceedings, Vol. 1195 (1), pp. 945-948.

Cai, M.-C., Niu, L.-S., Ma, X.-F., Shi, H.-J., 2010, "A Constitutive Description of the Strain Rate and Temperature Effects on the Mechanical Behavior of Materials", Mechanics of Materials, Vol. 42 (8), pp. 774-781.

Chen, G., Ren, C., Qin, X., Li, J., 2015, "Temperature Dependent Work Hardening in Ti-6Al-4V Alloy Over Large Temperature and Strain Rate Ranges: Experiments and Constitutive Modeling", Materials \& Design, Vol. 83, pp. 598-610.

Chocron, S., Erice, B., Anderson, C. E., 2011, "A New Plasticity and Failure Model for Ballistic Application", International Journal of Impact Engineering, Vol. 38 (8-9), pp. 755-764.

Choung, J., Nam, W., Lee, D., Song, C. Y., 2014, "Failure Strain Formulation via Average Stress Triaxiality of an EH36 High Strength Steel", Ocean Engineering, Vol. 91, pp. 218-226.

Hirsch, J., Al-Samman, T., 2013, "Superior Light Metals by Texture Engineering: Optimized Aluminum and Magnesium Alloys for Automotive Applications", Acta Materialia, Vol. 61 (3), pp. 818-843.

Keshavarz, A., Ghajar, R., Mirone, G., 2014, "A New Experimental Failure Model Based on Triaxiality Factor and Lode Angle for X-100 Pipeline Steel", International Journal of Mechanical Sciences, Vol. 80, pp. 175-182.

Kupchella, R., Stowe, D., Xiao, X., Algoso, A., Cogar, J., 2015, "Incorporation of Material Variability in the Johnson Cook Model", Procedia Engineering, Vol. 103, pp. 318-325.

Senthil, K., Iqbal, M. A., Chandel, P. S., Gupta, N., 2017, "Study of the Constitutive Behavior of 7075-T651 Aluminum Alloy", International Journal of Impact Engineering, Vol. 108, pp. 171-190.

Thepsonthi, T., Özel, T., 2015, "3-D Finite Element Process Simulation of Micro-end Milling Ti-6Al-4V Titanium Alloy: Experimental Validations on Chip Flow and Tool Wear", Journal of Materials Processing Technology, Vol. 221, pp. 128-145.

Valoppi, B., Bruschi, S., Ghiotti, A., Shivpuri, R., 2017, "Johnson-Cook Based Criterion Incorporating 
Stress Triaxiality and Deviatoric Effect for Predicting Elevated Temperature Ductility of Titanium Alloy Sheets", International Journal of Mechanical Sciences, Vol. 123 (01), pp. 94-105.

Wang, B., Liu, Z., 2016, "Evaluation on Fracture Locus of Serrated Chip Generation with Stress Triaxiality in High Speed Machining of Ti6Al4V", Materials and Design, Vol. 98, pp. 68-78.

Yuan, Z., Li, F., Qiao, H., Xiao, M., Cai, J., Li, J., 2013, "A Modified Constitutive Equation for Elevated Temperature Flow Behavior of Ti-6Al-4V Alloy Based on Double Multiple Nonlinear Regression", Materials Science and Engineering A, Vol. 578, pp. 260-270.

Zhang, D. N., Shangguan, Q. Q., Xie, C. J., Liu, F., 2015, "A Modified Johnson-Cook Model of Dynamic Tensile Behaviors for 7075-T6 Aluminum Alloy", Journal of Alloys and Compounds, Vol. 619, pp. 186-194.

Zhou, Z., Kuwamura, H., Nishida, A., 2011, "Effect of Micro Voids on Stress Triaxiality-Plastic Strain States of Notched Steels", Procedia Engineering, Vol. 10, pp. 1433-1439. 